Original Research Paper

\title{
Dynamic Kinematics of the Plan Balanced Chain at the Planar Module 3R
}

\author{
${ }^{1}$ Relly Victoria Petrescu, ${ }^{2}$ Raffaella Aversa, \\ ${ }^{2}$ Antonio Apicella and ${ }^{1}$ Florian Ion Tiberiu Petrescu \\ ${ }^{1}$ ARoTMM-IFToMM, Bucharest Polytechnic University, Bucharest, (CE), Romania \\ ${ }^{2}$ Department of Architecture and Industrial Design, Advanced Material Lab, \\ Second University of Naples, 81031 Aversa (CE), Italy
}

\section{Article history}

Received: 31-01-2018

Revised: 01-03-2018

Accepted: 8-03-2018

Corresponding Author: Florian Ion Tiberiu Petrescu ARoTMM-IFToMM, Bucharest Polytechnic University, Bucharest, (CE), Romania E-mail: scipub02@gmail.com

\begin{abstract}
Anthropomorphic robots are, as I have already said, in most of the most widespread and widely used works worldwide today, due to their ability to adapt quickly to forced work, working without breaks or breaks $24 \mathrm{~h}$ a day, without unpaid leave without asking for food, water, air, or salary. Anthropomorphic robots are supple, elegant, easy to configure and adapted to almost any required location, being the most flexible, more useful, more penetrating, easy to deploy and maintain. For the first time, these robots have asserted themselves in the automotive industry and especially in the automotive industry, today they have penetrated almost all industrial fields, being easily adaptable, flexible, dynamic, resilient, cheaper than other models, occupying a volume smaller but with a major working space. They can also work in toxic or dangerous environments, so used in dyeing, chemical cleaners, in chemical or nuclear environments, where they handle explosive objects, or in military missions to land or sea mines, even if they were banned to use, because there are still countries around the globe that use them, such as Afghanistan ... In the study of the dynamic movement of robots, i.e their real movement, when considering the actions and effects of the various forces that act upon them, it is important to know the real motion of the robots, ie the dynamic cinematic (the one imposed by the dynamics, that is, the forces in the mechanism).
\end{abstract}

Keywords: Anthropomorphic Mechatronic Systems, Robots, Total Static Balancing, Kinetostatics, Dynamics, Dynamic Kinematics

\section{Introduction}

Anthropomorphic robots are, as I have already said, in most of the most widespread and widely used works worldwide today, due to their ability to adapt quickly to forced work, working without breaks or breaks $24 \mathrm{~h}$ a day, without unpaid leave without asking for food, water, air, or salary. Anthropomorphic robots are supple, elegant, easy to configure and adapted to almost any required location, being the most flexible, more useful, more penetrating, easy to deploy and maintain. For the first time, these robots have asserted themselves in the automotive industry and especially in the automotive industry, today they have penetrated almost all industrial fields, being easily adaptable, flexible, dynamic, resilient, cheaper than other models, occupying a volume smaller but with a major working space. They can also work in toxic or dangerous environments, so used in dyeing, chemical cleaners, in chemical or nuclear environments, where they handle explosive objects, or in military missions to land or sea mines, even if they were banned to use, because there are still countries around the globe that use them, such as Afghanistan.

In the study of the dynamic movement of robots, ie their real movement, when considering the actions and effects of the various forces that act upon them, it is important to know the real motion of the robots, ie the dynamic cinematic (the one imposed by the dynamics, that is, the forces in the mechanism).

In some previous papers, the mechatronic module $3 \mathrm{R}$, plan, is a basic module on which the complete, geometric, 
cinematic, dynamic calculation of the anthropomorphic robots, the most used today's industrial robots, is built. The importance of the study of anthropomorphic robots has also been signaled, being today the most widespread robots worldwide, due to its simple design, construction, implementation, operation and maintenance. In addition, anthromomorphic systems are simpler from a technological and cheaper point of view, performing a continuous, demanding, repetitive work without any major maintenance problems. The basic module of these robots was also presented geometrically, cinematically, of the forces, of its total static balancing and of the forces that arise within or after balancing. In the present paper we want to highlight the dynamics of the already statically balanced total module. It has been presented in other works and studied matrix spatially, or more simply in a plan, but in this case, it is necessary to move from the working plane to the real space, or vice versa, passage that we will present in this study. In the basic plan module already presented in other geometric and cinematic works, we want to highlight some dynamic features such as static balancing, total balancing and determination of the strength of the module after balancing. Through a total static balancing, balancing the gravitational forces and moments generated by the forces of gravity is achieved, balancing the forces of inertia and the moments (couples) generated by the presence of inertial forces (not to be confused with the inertial moments of the mechanism, which appear separately from the other forces, being part of the inertial torsion of a mechanism and depending on both the inertial masses of the mechanism and its angular accelerations. Balancing the mechanism can be done through various methods. Partial balancing is achieved almost in all cases where the actuators (electric drive motors) are fitted with a mechanical reduction, a mechanical transmission, a sprocket, spiral gear, spool screw type. This results in a "forced" drive balancing from the transmission, which makes the operation of the assembly to be correct but rigid and with mechanical shocks. Such balancing is not possible when the actuators directly actuate the elements of the kinematic chain without using mechanical reducers (Antonescu and Petrescu, 1985; 1989; Antonescu et al., 1985a; 1985b; 1986; 1987; 1988; 1994; 1997; 2000a; 2000b; 2001; Aversa et al., 2017a; 2017b; $2017 \mathrm{c} ; 2017 \mathrm{~d} ; 2017 \mathrm{e} ; 2016 \mathrm{a} ; 2016 \mathrm{~b} ; 2016 \mathrm{c} ; 2016 \mathrm{~d}$; 2016e; 2016f; 2016g; 2016h; 2016i; 2016j; 2016k; 20161; 2016m; 2016n; 2016o; Berto et al., 2016a; 2016b; 2016c; 2016d; Cao et al., 2013; Dong et al., 2013; Comanescu, 2010; Franklin, 1930; He et al., 2013; Lee, 2013; Lin et al., 2013; Liu et al., 2013; Mirsayar et al.,
2017; Padula and Perdereau, 2013; Perumaal and Jawahar, 2013; Petrescu, 2011; 2015a; 2015b; Petrescu and Petrescu, 1995a; 1995b; 1997a; 1997b; 1997c; 2000a; 2000b; 2002a; 2002b; 2003; 2005a; 2005b; 2005c; 2005d; 2005e; 2011; 2012a; 2012b; 2013a; 2013b; 2016a; 2016b; 2016c; Petrescu et al., 2009; 2016; 2017a; 2017b; 2017c; 2017d; 2017e; 2017f; 2017g; 2017h; 2017i; 2017j; 2017k; 2017l; 2017m; 2017n; 2017o; 2017p; 2017q; 2017r; $2017 \mathrm{~s} ; 2017 \mathrm{t} ; 2017 \mathrm{u} ; 2017 \mathrm{v} ; 2017 \mathrm{w} ; 2017 \mathrm{x} ; 2017 \mathrm{y}$; 2017z; 2017aa; 2017ab; 2017ac; 2017ad; 2017ae).

Figure 1 shows the kinematic diagram of the planar chain and Fig. 2 shows the kinematic scheme of the space chain.

The mechanism in Fig. 1 (planar cinematic chain) must be balanced to have a normal operation.

Through a total static balancing, balancing the gravitational forces and moments generated by the forces of gravity is achieved, balancing the forces of inertia and the moments (couples) generated by the presence of inertial forces (not to be confused with the inertial moments of the mechanism, which appear separately from the other forces, being part of the inertial torsion of a mechanism and depending on both the inertial masses of the mechanism and its angular accelerations.

Balancing the mechanism can be done through various methods. Partial balancing is achieved almost in all cases where the actuators (electric drive motors) are fitted with a mechanical reduction, a mechanical transmission, a sprocket, spiral gear, spool screw type.

Such a reducer called the unisens (the movement allowed by it is a two-way rotation, but the transmission of the force and the motor moment can only be done in one direction, from the spindle to the worm gear, vice versa from the worm gear to the screw the force can not be transmitted and the movement is not possible by blocking the mechanism, which makes it apt to transmit the movement from the wheel of a vehicle to its wheels in the steering mechanism, not allowing the wheel forces due to the unevenness of the ground, to be transmitted to the steering wheel and implicitly to the driver, or this mechanism is suitable for mechanical meters so that they do not twist and vice versa etc.) can balance the transmission by letting the forces and motor moments unfold, but not allowing the kinematic elements to influence the movement through their forces of weight and inertia.

This results in a "forced" drive balancing from the transmission, which makes the operation of the assembly to be correct but rigid and with mechanical shocks.

Such balancing is not possible when the actuators directly actuate the elements of the kinematic chain without using mechanical reducers.

It is necessary in this situation for a real, permanent balancing. 


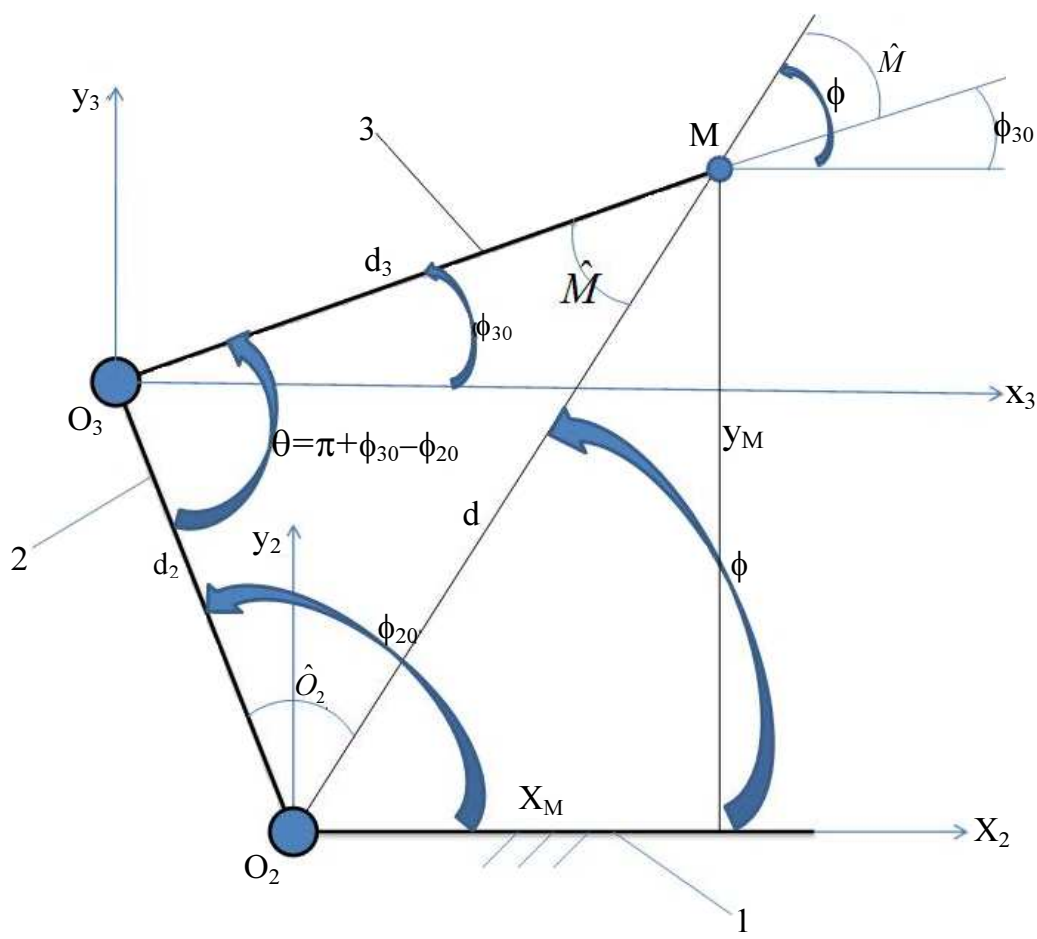

Fig. 1: The kinematic scheme of the plan chain

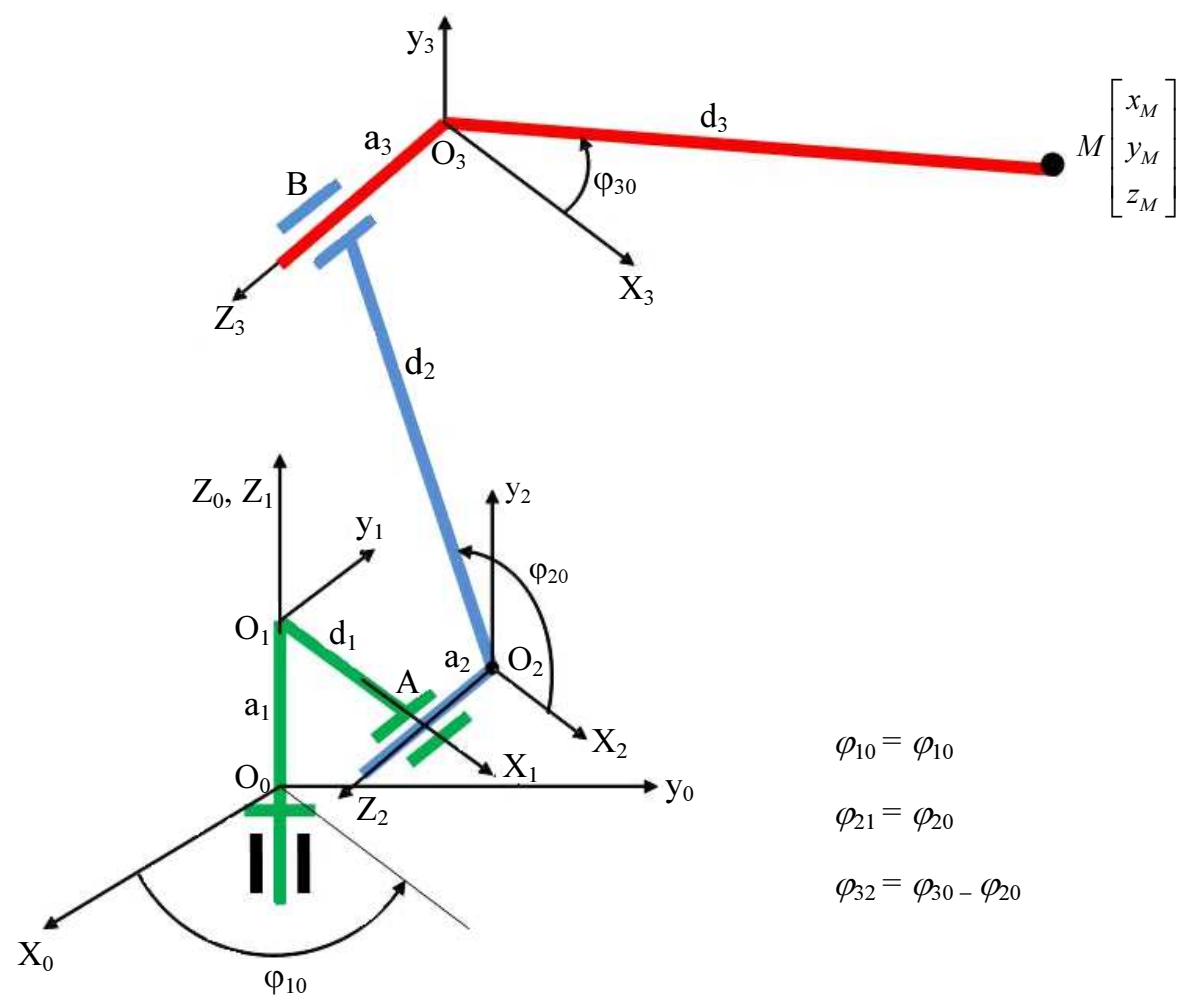

Fig. 2: The kinematic scheme of the spatial chain

In addition, in situations where hypoid reducers are used, it is also good to have a permanent, permanent static balancing that achieves a normal, quiet operation of the mechanism and the whole assembly. 


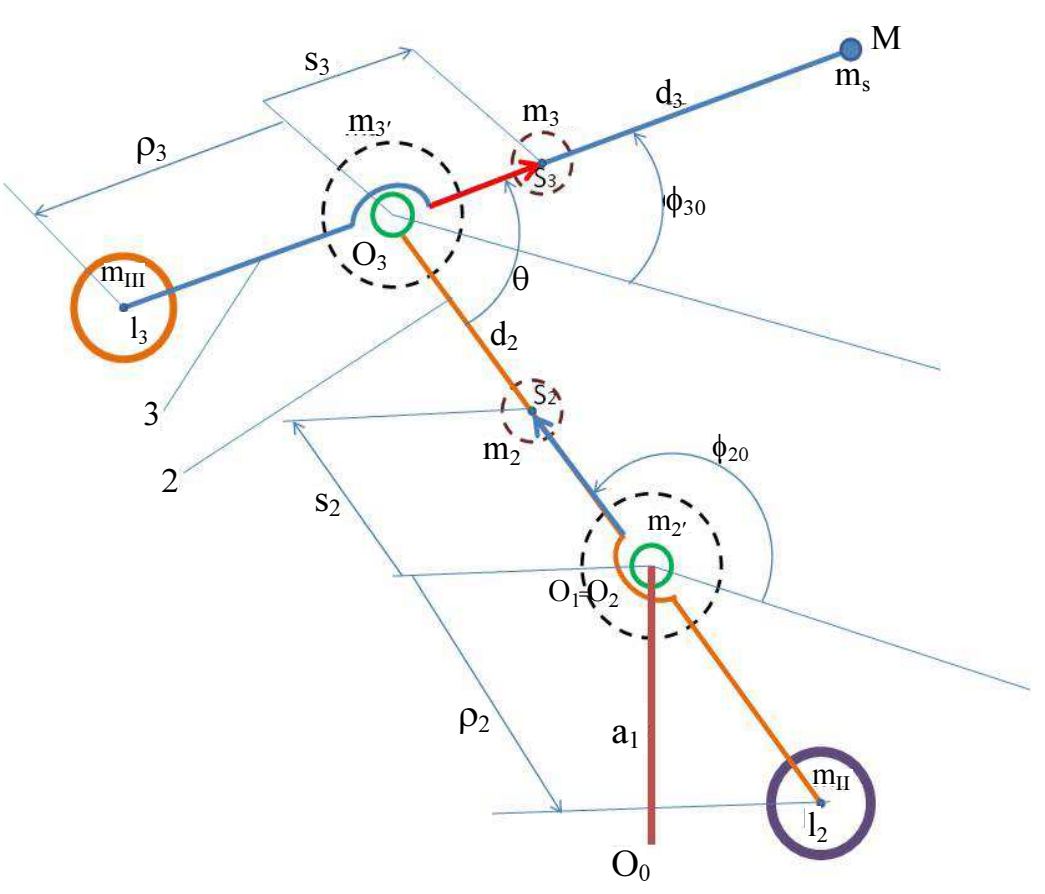

Fig. 3: Balancing the plan cinematic chain

As has already been shown, by balancing the static totality of a mobile cinematic chain, it is possible to balance the weight forces and couples produced by them, as well as balancing the inertial forces and the couples produced by them, but not balancing the moment of inertia.

Arcing balancing methods generally did not work very well, the springs having to be very well calibrated, so that the elastic forces realized (stored) by them are neither too small (insufficient balancing) nor too large (because prematurely kinematic elements and couplers and also greatly forces actuators). The most used method is the classic one, with additional counterweight masses, similar to traditional folk fountains. Total balancing of the open robotic kinematic chain is shown in Fig. 3.

\section{Materials and Methods}

The following "scenario" is being pursued. The following parameters are known:

$$
x_{M}, y_{M}, d_{2}, d_{3}, \omega_{2}, \dot{\theta}, M_{m_{2}}, M_{m_{3}}
$$

The moments of the electric motors (moments of the actuators) have values that vary in a narrow beach, along with the value of the angular speed of the respective engine, according to the characteristic diagram presented by the respective manufacturer. The variation is generally of the type shown in Fig 4.

As can be seen in Fig 4, the torque variation with the angular velocity is small so that the engine moment can be considered constant over the entire operating portion.
An important observation that should not be overlooked is that both electric, DC and AC motors have a stable operating characteristic.

If the load increases the angular speed of the motor and therefore the mechanism of the (open kinematic chain) decreases by adapting to the increased load and when the load decreases and the operation at a higher natural speed is possible, the angular speed of the actuator increases, according to its internal functional characteristics.

Returning to the dynamic kinematics data, we will continue to pursue computational relationships in a natural order.

It starts with the system (1), which determines the absolute angular velocity of the element 3 , that of the element 2 being the same as that of the actuator 2 and for the element 3 the actuator speed 2 must be summed up with that of the motor 3 .

Also, in the system (1), the absolute angular accelerations of the two kinematic elements 2 and 3 of the open-chain chain are determined, by means of known relations from the dynamics of the system. System (1) represents the 0 set of relationships in the dynamic kinematics:

$$
\left\{\begin{array}{l}
\omega_{3}=\dot{\theta}+\omega_{2} \\
\varepsilon_{2}=\frac{M_{m_{2}}}{m_{3^{\prime}} \cdot d_{2}^{2}+m_{2} \cdot s_{2}^{2}+m_{I I} \cdot \rho_{2}^{2}}=\frac{M_{m_{2}}}{J_{O_{2}}^{*}} \\
\varepsilon_{3}=\frac{M_{m_{3}}}{m_{s} \cdot d_{3}^{2}+m_{3} \cdot s_{3}^{2}+m_{I I I} \cdot \rho_{3}^{2}}=\frac{M_{m_{3}}}{J_{O_{3}}}
\end{array}\right.
$$



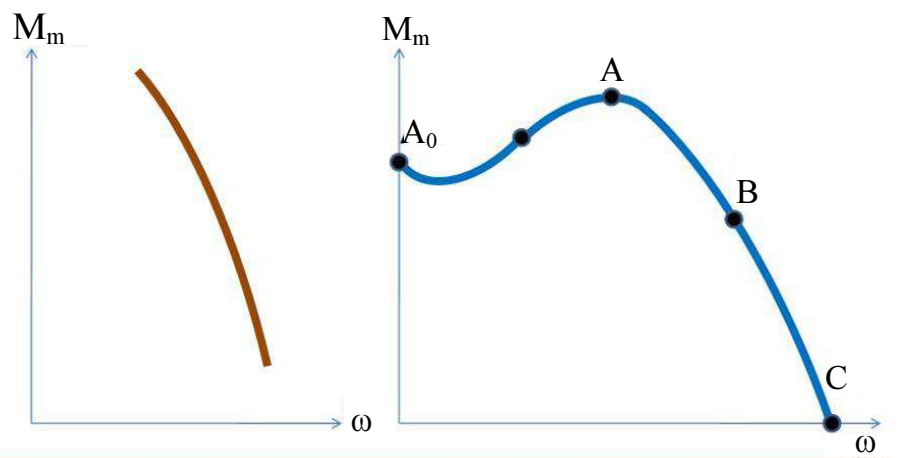

The characteristic of

the electic motor, of

direct current, with

parallel excitation
The feature of the asynchronous

electric motor has a stable function

only on the $\mathrm{ABC}$ portion

Fig. 4: Characteristics of DC and AC motors (three-phase asynchronous)

Further, the orderly kinematic parameters required with relations (2), considered to be the set I of relations, will be determined in turn:

$$
\left\{\begin{array}{l}
d=\sqrt{x_{M}^{2}+y_{M}^{2}} \\
d^{2}=x_{M}^{2}+y_{M}^{2} \\
\cos \phi=\frac{x_{M}}{d} \\
\sin \phi=\frac{y_{M}}{d} \\
\cos O_{2}=\frac{d_{2}^{2}+d^{2}-d_{3}^{2}}{2 \cdot d_{2} \cdot d} \\
\sin O_{2}=\frac{\sqrt{4 \cdot d_{2}^{2} \cdot d^{2}-\left(d_{2}^{2}+d^{2}-d_{3}^{2}\right)^{2}}}{2 \cdot d_{2} \cdot d} \\
\cos \phi_{2}=\cos \phi \cdot \cos O_{2} \mp \sin \phi \cdot \sin O_{2} \\
\sin \phi_{2}=\sin \phi \cdot \cos O_{2} \pm \sin O_{2} \cdot \cos \phi \\
x=d_{2} \cdot \cos \phi_{2} \\
y=d_{2} \cdot \sin \phi_{2} \\
\phi_{2}=\operatorname{semn}\left(\sin \phi_{2}\right) \cdot \arccos \left(\cos \phi_{2}\right) \\
\cos M=\frac{d_{3}^{2}+d^{2}-d_{2}^{2}}{2 \cdot d_{3} \cdot d} \\
\sin M=\frac{\sqrt{4 \cdot d_{3}^{2} \cdot d^{2}-\left(d_{3}^{2}+d^{2}-d_{2}^{2}\right)^{2}}}{2 \cdot d_{3} \cdot d} \\
\cos \phi_{3}=\cos \phi \cdot \cos M \pm \sin \phi \cdot \sin M \\
\sin \phi_{3}=\sin \phi \cdot \cos M \mp \sin M \cdot \cos \phi \\
\phi_{3}=\operatorname{semn}\left(\sin \phi_{3}\right) \cdot \arccos \left(\cos \phi_{3}\right)
\end{array}\right.
$$

\section{Results}

Follow the set II of dynamic kinematics relations, the system (3), which generates the linear speeds and accelerations of points $\mathrm{O} 3$ and $\mathrm{M}$. For point $\mathrm{O} 3$, they will be denoted without a letter as an index and for $\mathrm{M}$ will be denoted by M. The set III (4) determines the exact angular velocities and accelerations:

$$
\begin{aligned}
& \left\{\begin{array}{l}
\dot{x}=-y \cdot \omega_{2} \\
\dot{y}=x \cdot \omega_{2} \\
\ddot{x}=-x \cdot \omega_{2}^{2}-y \cdot \varepsilon_{2} \\
\ddot{y}=-y \cdot \omega_{2}^{2}+x \cdot \varepsilon_{2} \\
\dot{x}_{M}=\dot{x}-\left(y_{M}-y\right) \cdot \omega_{3} \\
\dot{y}_{M}=\dot{y}+\left(x_{M}-x\right) \cdot \omega_{3} \\
\ddot{x}_{M}=\ddot{x}-\left(\dot{y}_{M}-\dot{y}\right) \cdot \omega_{3}-\left(y_{M}-y\right) \cdot \varepsilon_{3} \\
\ddot{y}_{M}=\ddot{y}+\left(\dot{x}_{M}-\dot{x}\right) \cdot \omega_{3}+\left(x_{M}-x\right) \cdot \varepsilon_{3}
\end{array}\right. \\
& \left\{\begin{array}{l}
\omega_{2}=\frac{\dot{y} \cdot \cos \phi_{2}-\dot{x} \cdot \sin \phi_{2}}{d_{2}} \\
\omega_{3}=\frac{\left(\dot{y}_{M}-\dot{y}\right) \cdot \cos \phi_{3}-\left(\dot{x}_{M}-\dot{x}\right) \cdot \sin \phi_{3}}{d_{3}} \\
\varepsilon_{2}=\frac{\ddot{y} \cdot \cos \phi_{2}-\ddot{x} \cdot \sin \phi_{2}}{d_{2}} \\
\varepsilon_{3}=\frac{\left(\ddot{y}_{M}-\ddot{y}\right) \cdot \cos \phi_{3}-\left(\ddot{x}_{M}-\ddot{x}\right) \cdot \sin \phi_{3}}{d_{3}}
\end{array}\right.
\end{aligned}
$$

Enter the III values in II and recalculate II which become II '. Then with III in III is recalculated and III becomes III '. At small differences between the values III and III 'the iterative process stops, otherwise it must continue resulting II' 'and III' ', etc.

Important notice!

When the moments of the actuators are unknown (for example, there are used motorbikes, which are not technically familiar and therefore can not determine the mean or exact value of the torque generated by the 
angular speed imposed), or not know exactly the mass parameters of the elements and/or the external loads, one can use the simple or direct dynamic kinematics, without the set 0 (it is practically renounced to the dynamic relations, Lagrange) using only the relations in sets I, II and III, but also with known angular speeds.

Normally, the positions with the set of relations I are calculated, then the linear velocities and accelerations with the set II of existing relations are determined, knowing the desired angular speeds of the actuators and for their initial angular accelerations considering the values 0 , only in set II.

Then the exact angular speeds and the exact angular accelerations from the calculations made with the set of relationships III will then result, at which point it automatically follows at least one iteration, recalculating II 'and III'.

It is good in this situation to carry out an iteration or even two, even if the convergence is strong enough. Thus, II ', III' 'and maybe even II' 'and III' 'are also obtained.

\section{Discussion}

The masses and forces (exterior and interior) acting on the kinematic chain directly influence the average angular velocities of the balanced cinematic chain elements, $\omega_{2}, \omega_{3}$. These determine the real, dynamic kinematics of the mechanism by the systems of equations II and III, directly influencing the values of linear and angular velocities and accelerations for each point and element of the chain in each of its positions.

The actual angular accelerations of the two elements of the chain $\varepsilon_{2^{*}}, \varepsilon_{3^{*}}$ in each position obtained with III', or III", or even III"', cause variations in actuator moments, according to the relationships given by the system (5), variations which immediately change and the average input angular velocities $\omega_{2}, \omega_{3}$ bringing them to the instantaneous values $\omega_{2}, \omega_{3}$, determined from the characteristic diagrams of the two actuators (for actuator 2 , the angular velocity removed from its characteristic diagram according to the instantaneous moment of the motor torque will be passed directly as the new angular velocity $\omega_{2}$, but for the motor 3 according to the instantaneous calculated value of the motor moment $\mathrm{Mm} 3$ will determine from the characteristic diagram the instantaneous value of the angular speed of the actuator 3 $\dot{\theta}$, which will calculate the new instantaneous speed value $\omega_{3^{\prime}}=\omega_{2^{\prime}}+\dot{\theta}_{1}$ :

$$
\left\{\begin{array}{l}
M_{m_{2}}=J_{O_{2}}^{*} \cdot \varepsilon_{2} \\
M_{m_{3}}=J_{O_{3}} \cdot \varepsilon_{3} \\
M_{m_{2}}=\left(m_{2} \cdot s_{2}^{2}+m_{I I} \cdot \rho_{2}^{2}+m_{3^{\prime}} \cdot d_{2}^{2}\right) \cdot \ddot{\phi}_{20} \\
M_{m_{3}}=\left(m_{s} \cdot d_{3}^{2}+m_{3} \cdot s_{3}^{2}+m_{I I} \cdot \rho_{3}^{2}\right) \cdot \ddot{\phi}_{30}
\end{array}\right.
$$

It is possible to recalculate the relations of the systems II and III (which pass into II * and III * respectively) for each position of the mechanism (the open-plan cinematic chain), introducing in the linear speed and acceleration system II (for angular velocities and accelerations) values $\omega_{2^{\prime}}, \omega_{3^{\prime}}$ and $\varepsilon_{2^{*}}, \varepsilon_{3^{*}}$. With II $*$ is recalculated III *.

It is thus obtained from III * exact dynamic values, actual velocities and angular accelerations, of the mechanism (planar, open, balanced). Here again, several iterations can be performed (for example, using a computing program).

\section{Acknowledgement}

This text was acknowledged and appreciated by Dr. Veturia CHIROIU Honorific member of Technical Sciences Academy of Romania (ASTR) PhD supervisor in Mechanical Engineering.

\section{Funding Information}

Research contract: 1-Research contract: Contract number 36-5-4D/1986 from 24IV1985, beneficiary CNST RO (Romanian National Center for Science and Technology) Improving dynamic mechanisms.

2-Contract research integration. 19-91-3 from 29.03.1991; Beneficiary: MIS; TOPIC: Research on designing mechanisms with bars, cams and gears, with application in industrial robots.

3-Contract research. GR 69/10.05.2007: NURC in 2762; theme 8: Dynamic analysis of mechanisms and manipulators with bars and gears.

4-Labor contract, no. 35/22.01.2013, the UPB, "Stand for reading performance parameters of kinematics and dynamic mechanisms, using inductive and incremental encoders, to a Mitsubishi Mechatronic System" "PN-IIIN-CI-2012-1-0389".

All these matters are copyrighted! Copyrights: 394qodGnhhtej, from 17-02-2010 13:42:18; 463-vpstuCGsiy, from 20-03-2010 12:45:30; 631-sqfsgqvutm, from 2405-2010 16:15:22; 933-CrDztEfqow, from 07-01-2011 13:37:52.

\section{Author's Contributions}

This section should state the contributions made by each author in the preparation, development and publication of this manuscript.

\section{Ethics}

Authors should address any ethical issues that may arise after the publication of this manuscript. 


\section{References}

Antonescu, P. and F. Petrescu, 1985. An analytical method of synthesis of cam mechanism and flat stick. Proceedings of the 4th International Symposium on Theory and Practice of Mechanisms, (TPM' 89), Bucharest.

Antonescu, P. and F. Petrescu, 1989. Contributions to kinetoplast dynamic analysis of distribution mechanisms. Bucharest.

Antonescu, P., M. Oprean and F. Petrescu, 1985a. Contributions to the synthesis of oscillating cam mechanism and oscillating flat stick. Proceedings of the 4th International Symposium on Theory and Practice of Mechanisms, (TPM' 85), Bucharest.

Antonescu, P., M. Oprean and F. Petrescu, 1985b. At the projection of the oscillate cams, there are mechanisms and distribution variables. Proceedings of the 5th Conference of Engines, Automobiles, Tractors and Agricultural Machines, (TAM' 58), IMotors and Cars, Brasov.

Antonescu, P., M. Oprean and F. Petrescu, 1986. Projection of the profile of the rotating camshaft acting on the oscillating plate with disengagement. Proceedings of the 3rd National Computer-aided Design Symposium in the field of Mechanisms and Machine Parts, (MMP' 86), Brasov.

Antonescu, P., M. Oprean and F. Petrescu, 1987. Dynamic analysis of the cam distribution mechanisms. Proceedings of the 7th National Symposium on Industrial Robots and Space Mechanisms, (RSM' 87), Bucharest.

Antonescu, P., M. Oprean and F. Petrescu, 1988. Analytical synthesis of Kurz profile, rotating the flat cam. Mach, Build. Rev.

Antonescu, P., F. Petrescu and O. Antonescu, 1994. Contributions to the synthesis of the rotating cam mechanism and the tip of the balancing tip. Brasov.

Antonescu, P., F. Petrescu and D. Antonescu, 1997. Geometrical synthesis of the rotary cam and balance tappet mechanism. Bucharest, 3: 23-23.

Antonescu, P., F. Petrescu and O. Antonescu, 2000a. Contributions to the synthesis of the rotary disc-cam profile. Proceedings of the 8th International Conference on the Theory of Machines and Mechanisms, (TMM' 00), Liberec, Czech Republic, pp: 51-56.

Antonescu, P., F. Petrescu and O. Antonescu, $2000 \mathrm{~b}$. Synthesis of the rotary cam profile with balance follower. Proceedings of the 8th Symposium on Mechanisms and Mechanical Transmissions, (MMT'00), Timişoara, pp: 39-44.

Antonescu, P., F. Petrescu and O. Antonescu, 2001. Contributions to the synthesis of mechanisms with rotary disc-cam. Proceedings of the 8th IFToMM International Symposium on Theory of Machines and Mechanisms, (TMM' 01), Bucharest, ROMANIA, pp: 31-36.
Aversa, R., R.V.V. Petrescu, A. Apicella and F.I.T. Petrescu, 2017a. Nano-diamond hybrid materials for structural biomedical application. Am. J. Biochem. Biotechnol., 13: 34-41. DOI: 10.3844/ajbbsp.2017.34.41

Aversa, R., R.V. Petrescu, B. Akash, R.B. Bucinell and J.M. Corchado et al., 2017b. Kinematics and forces to a new model forging manipulator. Am. J. Applied Sci., 14: 60-80. DOI: 10.3844/ajassp.2017.60.80

Aversa, R., R.V. Petrescu, A. Apicella, F.I.T. Petrescu and J.K. Calautit et al., 2017c. Something about the $\mathrm{V}$ engines design. Am. J. Applied Sci., 14: 34-52. DOI: 10.3844/ajassp.2017.34.52

Aversa, R., D. Parcesepe, R.V.V. Petrescu, F. Berto and G. Chen et al., 2017d. Process ability of bulk metallic glasses. Am. J. Applied Sci., 14: 294-301. DOI: 10.3844/ajassp.2017.294.301

Aversa, R., R.V.V. Petrescu, B. Akash, R.B. Bucinell and J.M. Corchado et al., 2017e. Something about the balancing of thermal motors. Am. J. Eng. Applied Sci., 10: 200.217. DOI: 10.3844/ajeassp.2017.200.217

Aversa, R., F.I.T. Petrescu, R.V. Petrescu and A. Apicella, 2016a. Biomimetic FEA bone modeling for customized hybrid biological prostheses development. Am. J. Applied Sci., 13: 1060-1067. DOI: 10.3844/ajassp.2016.1060.1067

Aversa, R., D. Parcesepe, R.V. Petrescu, G. Chen and F.I.T. Petrescu et al., 2016b. Glassy amorphous metal injection molded induced morphological defects. Am. J. Applied Sci., 13: 1476-1482. DOI: 10.3844/ajassp.2016.1476.1482

Aversa, R., R.V. Petrescu, F.I.T. Petrescu and A. Apicella, 2016c. Smart-factory: Optimization and process control of composite centrifuged pipes. Am. J. Applied Sci., 13: 1330-1341. DOI: 10.3844/ajassp.2016.1330.1341

Aversa, R., F. Tamburrino, R.V. Petrescu, F.I.T. Petrescu and M. Artur et al., 2016d. Biomechanically inspired shape memory effect machines driven by muscle like acting NiTi alloys. Am. J. Applied Sci., 13: 1264-1271. DOI: 10.3844/ajassp.2016.1264.1271

Aversa, R., E.M. Buzea, R.V. Petrescu, A. Apicella and M. Neacsa et al., 2016e. Present a mechatronic system having able to determine the concentration of carotenoids. Am. J. Eng. Applied Sci., 9: 1106-1111. DOI: 10.3844/ajeassp.2016.1106.1111

Aversa, R., R.V. Petrescu, R. Sorrentino, F.I.T. Petrescu and A. Apicella, 2016f. Hybrid ceramo-polymeric nanocomposite for biomimetic scaffolds design and preparation. Am. J. Eng. Applied Sci., 9: 1096-1105. DOI: 10.3844/ajeassp.2016.1096.1105

Aversa, R., V. Perrotta, R.V. Petrescu, C. Misiano and F.I.T. Petrescu et al., 2016g. From structural colors to super-hydrophobicity and achromatic transparent protective coatings: Ion plating plasma assisted $\mathrm{TiO}_{2}$ and $\mathrm{SiO}_{2}$ nano-film deposition. Am. J. Eng. Applied Sci., 9: 1037-1045.

DOI: $10.3844 /$ ajeassp.2016.1037.1045 
Aversa, R., R.V. Petrescu, F.I.T. Petrescu and A. Apicella, 2016h. Biomimetic and evolutionary design driven innovation in sustainable products development. Am. J. Eng. Applied Sci., 9: 1027-1036. DOI: 10.3844/ajeassp.2016.1027.1036

Aversa, R., R.V. Petrescu, A. Apicella and F.I.T. Petrescu, 2016i. Mitochondria are naturally micro robots - a review. Am. J. Eng. Applied Sci., 9: 991-1002. DOI: 10.3844 /ajeassp.2016.991.1002

Aversa, R., R.V. Petrescu, A. Apicella and F.I.T. Petrescu, 2016j. We are addicted to vitamins $\mathrm{C}$ and E-A review. Am. J. Eng. Applied Sci., 9: 1003-1018. DOI: 10.3844/ajeassp.2016.1003.1018

Aversa, R., R.V. Petrescu, A. Apicella and F.I.T. Petrescu, 2016k. Physiologic human fluids and swelling behavior of hydrophilic biocompatible hybrid ceramo-polymeric materials. Am. J. Eng. Applied Sci., 9: 962-972. DOI: 10.3844/ajeassp.2016.962.972

Aversa, R., R.V. Petrescu, A. Apicella and F.I.T. Petrescu, 20161. One can slow down the aging through antioxidants. Am. J. Eng. Applied Sci., 9: 1112-1126. DOI: 10.3844/ajeassp.2016.1112.1126

Aversa, R., R.V. Petrescu, A. Apicella and F.I.T. Petrescu, 2016m. About homeopathy or «Similia Similibus Curentur 》. Am. J. Eng. Applied Sci., 9: 1164-1172. DOI: 10.3844/ajeassp.2016.1164.1172

Aversa, R., R.V. Petrescu, A. Apicella and F.I.T. Petrescu, 2016n. The basic elements of life's. Am. J. Eng. Applied Sci., 9: 1189-1197.

DOI: 10.3844/ajeassp.2016.1189.1197

Aversa, R., F.I.T. Petrescu, R.V. Petrescu and A. Apicella, 2016o. Flexible stem trabecular prostheses. Am. J. Eng. Applied Sci., 9: 1213-1221.

DOI: 10.3844/ajeassp.2016.1213.1221

Berto, F., R.V.V. Petrescu and F.I.T. Petrescu, 2016a. A review of recent results on $3 \mathrm{D}$ effects. Am. J. Eng. Applied Sci., 9: 1247-1260.

DOI: 10.3844/ajeassp.2016.1247.1260

Berto, F., R.V.V. Petrescu and F.I.T. Petrescu, $2016 \mathrm{~b}$. Three-dimensional in bonded joints: A short review. Am. J. Eng. Applied Sci., 9: 1261-1268. DOI: 10.3844 /ajeassp.2016.1261.1268

Berto, F., A. Gagani, R.V.V. Petrescu and F.I.T. Petrescu, 2016c. Key-hole notches in isostatic graphite: A review of some recent data. Am. J. Eng. Applied Sci., 9: 1292-1300. DOI: 10.3844/ajeassp.2016.1292.1300

Berto, F., A. Gagani, R. Aversa, R.V.V. Petrescu and A. Apicella et al., 2016d. Multiaxial fatigue strength to notched specimens made of 40CrMoV13.9. Am. J. Eng. Applied Sci., 9: 1269-1291.

DOI: 10.3844/ajeassp.2016.1269.1291

Cao, W., H. Ding, Z. Bin and C. Ziming, 2013. New structural representation and digital-analysis platform for symmetrical parallel mechanisms. Int. J. Adv. Robotic Sys. DOI: 10.5772/56380
Comanescu, A., 2010. Bazele Modelarii Mecanismelor. 1st Edn., E. Politeh, Press, Bucureşti, pp: 274.

Dong, H., N. Giakoumidis, N. Figueroa and N. Mavridis, 2013. Approaching behaviour monitor and vibration indication in developing a General Moving Object Alarm System (GMOAS). Int. J. Adv. Robotic Sys. DOI: $10.5772 / 56586$

Franklin, D.J., 1930. Ingenious Mechanisms for Designers and Inventors. 1st Edn., Industrial Press Publisher.

He, B., Z. Wang, Q. Li, H. Xie and R. Shen, 2013. An analytic method for the kinematics and dynamics of a multiple-backbone continuum robot. IJARS. DOI: $10.5772 / 54051$

Lee, B.J., 2013. Geometrical derivation of differential kinematics to calibrate model parameters of flexible manipulator. Int. J. Adv. Robotic Sys. DOI: $10.5772 / 55592$

Lin, W., B. Li, X. Yang and D. Zhang, 2013. Modelling and control of inverse dynamics for a 5-DOF parallel kinematic polishing machine. Int. J. Adv. Robotic Sys. DOI: 10.5772/54966

Liu, H., W. Zhou, X. Lai and S. Zhu, 2013. An efficient inverse kinematic algorithm for a PUMA560-structured robot manipulator. IJARS. DOI: $10.5772 / 56403$

Mirsayar, M.M., V.A. Joneidi, R.V.V. Petrescu, F.I.T. Petrescu and F. Berto, 2017. Extended MTSN criterion for fracture analysis of soda lime glass. Eng. Fracture Mechan., 178: 50-59.

DOI: 10.1016/j.engfracmech.2017.04.018

Padula, F. and V. Perdereau, 2013. An on-line path planner for industrial manipulators. Int. J. Adv. Robotic Sys. DOI: 10.5772/55063

Perumaal, S. and N. Jawahar, 2013. Automated trajectory planner of industrial robot for pick-andplace task. IJARS. DOI: 10.5772/53940

Petrescu, F. and R. Petrescu, 1995a. Contributions to optimization of the polynomial motion laws of the stick from the internal combustion engine distribution mechanism. Bucharest, 1: 249-256.

Petrescu, F. and R. Petrescu, 1995b. Contributions to the synthesis of internal combustion engine distribution mechanisms. Bucharest, 1: 257-264.

Petrescu, F. and R. Petrescu, 1997a. Dynamics of cam mechanisms (exemplified on the classic distribution mechanism). Bucharest, 3: 353-358.

Petrescu, F. and R. Petrescu, 1997b. Contributions to the synthesis of the distribution mechanisms of internal combustion engines with a Cartesian coordinate method. Bucharest, 3: 359-364.

Petrescu, F. and R. Petrescu, 1997c. Contributions to maximizing polynomial laws for the active stroke of the distribution mechanism from internal combustion engines. Bucharest, 3: 365-370. 
Petrescu, F. and R. Petrescu, 2000a. Synthesis of distribution mechanisms by the rectangular (Cartesian) coordinate method. Proceedings of the 8th National Conference on International Participation (CIP' 00), Craiova, Romania, pp: 297-302.

Petrescu, F. and R. Petrescu, 2000b. The design (synthesis) of cams using the polar coordinate method (triangle method). Proceedings of the 8th National Conference on International Participation (CIP' 00), Craiova, Romania, pp: 291-296.

Petrescu, F. and R. Petrescu, 2002a. Motion laws for cams. Proceedings of the International Computer Assisted Design, National Symposium with Participation, (SNP' 02), Braşov, pp: 321-326.

Petrescu, F. and R. Petrescu, 2002b. Camshaft dynamics elements. Proceedings of the International Computer Assisted Design, National Participation Symposium, (SNP' 02), Braşov, pp: 327-332.

Petrescu, F. and R. Petrescu, 2003. Some elements regarding the improvement of the engine design. Proceedings of the National Symposium, Descriptive Geometry, Technical Graphics and Design, (GTD' 03), Braşov, pp: 353-358.

Petrescu, F. and R. Petrescu, 2005a. The cam design for a better efficiency. Proceedings of the International Conference on Engineering Graphics and Design, (EGD' 05), Bucharest, pp: 245-248.

Petrescu, F. and R. Petrescu, 2005b. Contributions at the dynamics of cams. Proceedings of the 9th IFToMM International Symposium on Theory of Machines and Mechanisms, (TMM' 05), Bucharest, Romania, pp: 123-128.

Petrescu, F. and R. Petrescu, 2005c. Determining the dynamic efficiency of cams. Proceedings of the 9th IFToMM International Symposium on Theory of Machines and Mechanisms, (TMM' 05), Bucharest, Romania, pp: 129-134.

Petrescu, F. and R. Petrescu, 2005d. An original internal combustion engine. Proceedings of the 9th IFToMM International Symposium on Theory of Machines and Mechanisms, (TMM' 05), Bucharest, Romania, pp: 135-140.

Petrescu, F. and R. Petrescu, 2005e. Determining the mechanical efficiency of Otto engine's mechanism. Proceedings of the 9th IFToMM International Symposium on Theory of Machines and Mechanisms, (TMM 05), Bucharest, Romania, pp: 141-146.

Petrescu, F.I. and R.V. Petrescu, 2011. Mechanical Systems, Serial and Parallel (Romanian). 1st Edn., LULU Publisher, London, UK, pp: 124.

Petrescu, F.I. and R.V. Petrescu, 2012a. Kinematics of the planar quadrilateral mechanism. ENGEVISTA, 14: 345-348.

Petrescu, F.I. and R.V. Petrescu, 2012b. MecatronicaSisteme Seriale si Paralele. 1st Edn., Create Space Publisher, USA, pp: 128.
Petrescu, F.I. and R.V. Petrescu, 2013a. Cinematics of the 3R dyad. ENGEVISTA, 15: 118-124.

Petrescu, F.I. and R.V. Petrescu, 2013b. Forces and efficiency of cams. Int. Rev. Mechanical Eng.

Petrescu, F.I. and R.V. Petrescu, 2016a. Parallel moving mechanical systems kinematics. ENGEVISTA, 18: 455-491.

Petrescu, F.I. and R.V. Petrescu, 2016b. Direct and inverse kinematics to the anthropomorphic robots. ENGEVISTA, 18: 109-124.

Petrescu, F.I. and R.V. Petrescu, 2016c. Dynamic cinematic to a structure 2R. Revista Geintec-Gestao Inovacao E Tecnol., 6: 3143-3154.

Petrescu, R.V., R. Aversa, A. Apicella and F.I. Petrescu, 2016. Future medicine services robotics. Am. J. Eng. Applied Sci., 9: 1062-1087.

DOI: 10.3844/ajeassp.2016.1062.1087

Petrescu, F.I., B. Grecu, A. Comanescu and R.V. Petrescu, 2009. Some mechanical design elements. Proceeding of the International Conference on Computational Mechanics and Virtual Engineering, (MVE' 09), Braşov, pp: 520-525.

Petrescu, F.I., 2011. Teoria Mecanismelor si a Masinilor: Curs Si Aplicatii. 1st Edn., CreateSpace Independent Publishing Platform. ISBN-10: 1468015826. pp: 432.

Petrescu, F.I.T., 2015a. Geometrical synthesis of the distribution mechanisms. Am. J. Eng. Applied Sci., 8: 63-81. DOI: 10.3844/ajeassp.2015.63.81

Petrescu, F.I.T., 2015b. Machine motion equations at the internal combustion heat engines. Am. J. Eng. Applied Sci., 8: 127-137. DOI: 10.3844/ajeassp.2015.127.137

Petrescu, R.V., R. Aversa, B. Akash, R. Bucinell and J. Corchado et al., 2017a. Yield at thermal engines internal combustion. Am. J. Eng. Applied Sci., 10: 243-251. DOI: 10.3844/ajeassp.2017.243.251

Petrescu, R.V., R. Aversa, B. Akash, B. Ronald and J. Corchado et al., 2017b. Velocities and accelerations at the 3R mechatronic systems. Am. J. Eng. Applied Sci., 10: 252-263. DOI: 10.3844/ajeassp.2017.252.263

Petrescu, R.V., R. Aversa, B. Akash, R. Bucinell and J. Corchado et al., 2017c. Anthropomorphic solid structures n-r kinematics. Am. J. Eng. Applied Sci., 10: 279-291. DOI: 10.3844/ajeassp.2017.279.291

Petrescu, R.V., R. Aversa, B. Akash, R. Bucinell and J. Corchado et al., 2017d. Inverse kinematics at the anthropomorphic robots, by a trigonometric method. Am. J. Eng. Applied Sci., 10: 394-411. DOI: 10.3844/ajeassp.2017.394.411

Petrescu, R.V., R. Aversa, B. Akash, R. Bucinell and J. Corchado et al., 2017e. Forces at internal combustion engines. Am. J. Eng. Applied Sci., 10: 382-393. DOI: 10.3844/ajeassp.2017.382.393

Petrescu, R.V., R. Aversa, B. Akash, R. Bucinell and J. Corchado et al., 2017f. Gears-Part I. Am. J. Eng. Applied Sci., 10: 457-472.

DOI: 10.3844/ajeassp.2017.457.472 
Petrescu, R.V., R. Aversa, B. Akash, R. Bucinell and J. Corchado et al., 2017g. Gears-part II. Am. J. Eng. Applied Sci., 10: 473-483.

DOI: 10.3844/ajeassp.2017.473.483

Petrescu, R.V., R. Aversa, B. Akash, R. Bucinell and J. Corchado et al., 2017h. Cam-gears forces, velocities, powers and efficiency. Am. J. Eng. Applied Sci., 10: 491-505.

DOI: 10.3844/ajeassp.2017.491.505

Petrescu, R.V., R. Aversa, B. Akash, R. Bucinell and J. Corchado et al., 2017i. Dynamics of mechanisms with cams illustrated in the classical distribution. Am. J. Eng. Applied Sci., 10: 551-567. DOI: 10.3844/ajeassp.2017.551.567

Petrescu, R.V., R. Aversa, B. Akash, R. Bucinell and J. Corchado et al., 2017j. Testing by nondestructive control. Am. J. Eng. Applied Sci., 10: 568-583. DOI: 10.3844/ajeassp.2017.568.583

Petrescu, R.V., R. Aversa, A. Apicella and F.I.T. Petrescu, 2017k. Transportation engineering. Am. J. Eng. Applied Sci., 10: 685-702.

DOI: 10.3844/ajeassp.2017.685.702

Petrescu, R.V., R. Aversa, S. Kozaitis, A. Apicella and F.I.T. Petrescu, 20171. The quality of transport and environmental protection, part I. Am. J. Eng. Applied Sci., 10: 738-755.

DOI: 10.3844/ajeassp.2017.738.755

Petrescu, R.V., R. Aversa, B. Akash, R. Bucinell and J. Corchado et al., 2017m. Modern propulsions for aerospace-a review. J. Aircraft Spacecraft Technol., 1: 1-8. DOI: $10.3844 /$ jastsp.2017.1.8

Petrescu, R.V., R. Aversa, B. Akash, R. Bucinell and J. Corchado et al., 2017n. Modern propulsions for aerospace-part II. J. Aircraft Spacecraft Technol., 1: 9-17. DOI: $10.3844 /$ jastsp.2017.9.17

Petrescu, R.V., R. Aversa, B. Akash, R. Bucinell and J. Corchado et al., 2017o. History of aviation-a short review. J. Aircraft Spacecraft Technol., 1: 30-49. DOI: 10.3844/jastsp.2017.30.49

Petrescu, R.V., R. Aversa, B. Akash, R. Bucinell and J. Corchado et al., 2017p. Lockheed martin-a short review. J. Aircraft Spacecraft Technol., 1: 50-68. DOI: 10.3844 jastsp.2017.50.68

Petrescu, R.V., R. Aversa, B. Akash, J. Corchado and F. Berto et al., 2017q. Our universe. J. Aircraft Spacecraft Technol., 1: 69-79. DOI: 10.3844 jastsp.2017.69.79

Petrescu, R.V., R. Aversa, B. Akash, J. Corchado and F. Berto et al., 2017r. What is a UFO? J. Aircraft Spacecraft Technol., 1: 80-90. DOI: 10.3844 /jastsp.2017.80.90

Petrescu, R.V., R. Aversa, B. Akash, J. Corchado and F. Berto et al., 2017s. About bell helicopter FCX001 concept aircraft-a short review. J. Aircraft Spacecraft Technol., 1: 91-96.

DOI: $10.3844 /$ jastsp.2017.91.96
Petrescu, R.V., R. Aversa, B. Akash, J. Corchado and F. Berto et al., 2017t. Home at airbus. J. Aircraft Spacecraft Technol., 1: 97-118.

DOI: $10.3844 /$ jastsp.2017.97.118

Petrescu, R.V., R. Aversa, B. Akash, J. Corchado and F. Berto et al., 2017u. Airlander. J. Aircraft Spacecraft Technol., 1: 119-148. DOI: 10.3844 /jastsp.2017.119.148

Petrescu, R.V., R. Aversa, B. Akash, J. Corchado and F. Berto et al., 2017v. When boeing is dreaming-a review. J. Aircraft Spacecraft Technol., 1: 149-161. DOI: 10.3844/jastsp.2017.149.161

Petrescu, R.V., R. Aversa, B. Akash, J. Corchado and F. Berto et al., 2017w. About Northrop Grumman. J. Aircraft Spacecraft Technol., 1: 162-185. DOI: $10.3844 /$ jastsp.2017.162.185

Petrescu, R.V., R. Aversa, B. Akash, J. Corchado and F. Berto et al., 2017x. Some special aircraft. J. Aircraft Spacecraft Technol., 1: 186-203. DOI: $10.3844 /$ jastsp.2017.186.203

Petrescu, R.V., R. Aversa, B. Akash, J. Corchado and F. Berto et al., 2017y. About helicopters. J. Aircraft Spacecraft Technol., 1: 204-223. DOI: 10.3844/jastsp.2017.204.223

Petrescu, R.V., R. Aversa, B. Akash, F. Berto and A. Apicella et al., 2017z. The modern flight. J. Aircraft Spacecraft Technol., 1: 224-233. DOI: $10.3844 /$ jastsp.2017.224.233

Petrescu, R.V., R. Aversa, B. Akash, F. Berto and A. Apicella et al., 2017aa. Sustainable energy for aerospace vessels. J. Aircraft Spacecraft Technol., 1: 234-240. DOI: 10.3844/jastsp.2017.234.240

Petrescu, R.V., R. Aversa, B. Akash, F. Berto and A. Apicella et al., 2017ab. Unmanned helicopters. J. Aircraft Spacecraft Technol., 1: 241-248. DOI: $10.3844 /$ jastsp.2017.241.248

Petrescu, R.V., R. Aversa, B. Akash, F. Berto and A. Apicella et al., 2017ac. Project HARP. J. Aircraft Spacecraft Technol., 1: 249-257. DOI: $10.3844 /$ jastsp.2017.249.257

Petrescu, R.V., R. Aversa, B. Akash, F. Berto and A. Apicella et al., 2017ad. Presentation of romanian engineers who contributed to the development of global aeronautics-part I. J. Aircraft Spacecraft Technol., 1: 258-271. DOI: 10.3844 /jastsp.2017.258.271

Petrescu, R.V., R. Aversa, B. Akash, F. Berto and A. Apicella et al., 2017ae. A first-class ticket to the planet mars, please. J. Aircraft Spacecraft Technol., 1: 272-281. DOI: 10.3844/jastsp.2017.272.281 